\title{
Correction to: Exploring the Utility of Longitudinal Clinical Electives in Training Dual-Degree Students
}

\author{
Nicholas Theodosakis ${ }^{1} \cdot$ Kathleen P. White $^{1} \cdot$ John Encandela $^{1}$
}

Published online: 3 October 2017

(C) International Association of Medical Science Educators 2017

\section{Correction to: Med Sci Educ}

https://doi.org/10.1007/s40670-017-0470-9

Part of the text of the Results section labeled "Participants" has been updated to read: Three cohorts with a total of 37 MSTP students had begun PhD research, but had not yet completed the training program while we were interviewing. 